\title{
ANALISIS PENGARUH PENERAPAN TOTAL QUALITY MANAGEMENT DAN JUST IN TIME PADA INDUSTRI MANUFAKTUR (STUDI EMPIRIS PADA PERUSAHAAN MANUFAKTUR DI BOGOR DAN TANGERANG)
}

\author{
Linda Santioso dan Cynthia Maharani \\ Fakultas Ekonomi Universitas Tarumanagara \\ Email: linda.santisoso@gmail.com
}

\begin{abstract}
As we know the main value to be achieved by a company is to meet the desires of its customers. Total Quality Management represents the creation of value by basing on the quality provided to consumers, while the Just In Time creating value based on a given speed. Manufacturing industry is an industry that is becoming an important part of the national economy, but some manufacturing companies in Indonesia implementing TQM and JIT just still a concept. This study tries to analyze the impact of the implementation of Total Quality Management and Just In Time for Delivery Performance. The variables used in this study include Total Quality Management and Just In Time as anindependent variable, and Delivery Performance as the dependent variable. The research methodology used in this study is a survey method using a questionnaire as a data collection tool. This study used a sample 6 manufacturing company located in Bogor and Tangerang. The results of the analysis using regression model showed that Total Quality Management and Just In Time has a significant impact on Delivery Performance.
\end{abstract}

Key words: Total Quality Management (TQM), Just In Time (JIT), Delivery Performance.

\begin{abstract}
Abstrak: Seperti yang kita ketahui nilai utama yang ingin dicapai oleh suatu perusahan adalah memenuhi keinginan para pelanggannya. Total Quality Management mewakili penciptaan nilai dengan mendasarkan pada kualitas yang diberikan pada konsumen, sedangkan Just InTime menciptakan nilai berdasarkan kecepatan yang diberikan. Industri manufaktur adalah industri yang menjadibagian penting dari perekonomian nasional, namun beberapa perusahaan manufaktur di Indonesia menerapkan TQM dan JIT hanya masih sebatas konsep. Penelitian ini mencoba menganalisis mengenai dampak penerapan Total Quality Management dan Just In Time terhadap Delivery Performance.Variabel yang digunakan dalam penelitian ini antara lainTotal Quality Management dan Just In Time sebagai variabel independen, serta Delivery Performance sebagai variabel dependen. Metodologi penelitian yang digunakan dalam penelitian ini adalah metode survei dengan menggunakan kuesioner sebagai alat pengumpulan data. Penelitian ini menggunakan 6 sampel perusahaan manufaktur yang berada di Bogor dan Tangerang. Hasil analisis dengan menggunakan model regresi menunjukkan bahwa Total Quality Management dan Just I
\end{abstract}

\section{PENDAHULUAN}

Seiring dengan perkembangan globalisasi, serta diikuti dengan kemajuan teknologi yang semakin pesat membuat persaingan di bidang ekonomi semakin tinggi, baik dari perusahaan lokal maupun dengan perusahaan asing, dimanaperusahaan dituntut untuk 
selalu mampu beradaptasi di lingkungan yang berubah-ubah dan tingkat bersaing di dalam pasar global. Untuk itu setiap perusahaan yang ingin memenangi persaingan di dalam dunia bisnis harus mempunyai suatu strategi yang dapat meningkatkan kinerja mereka, menghadapi perubahan, serta persaingan di era globalisasi ini. Pada umumya, suatu kinerja perusahaan dapat menjadi alat ukur bagi perusahan untuk menilai sejauh mana keberhasilan perusahaan dalam mencapai tujuan yang telah ditetapkan sebelumnya.

Dengan adanya strategi dalam menghadapi persaingan tentunya akan membuat suatu perusahaan memiliki satu nilai yang berbeda dibandingkan dengan perusahaan lainnya. Menurut Meylianti dan Mulia (2009: 113) untuk menjadi yang terbaik, salah satu cara yang dapat dilakukan perusahaan adalah dengan memiliki corporate strategy yang baik sehingga perusahaan dapat meciptakan suatu competitive advantage. Heizer dan Render dalam Meylianti dan Mulia (2009: 113) mengatakan bahwa "Competitive advantage implies the creation of a system that has a unique advantage over competitors. The Idea is to create customer value in an efficient and sustainable way", sehingga dapat diartikan competitiveadvantage atau keunggulan kompetitif merupakan suatu penciptaan sistem yang memiliki suatu keunggulan yang unik bila dibandingkan dengan pesaing. Inti dari keunggulan kompetitif adalah untuk menciptakan nilai di mata pelanggan dengan cara yang efisien dan berkelanjutan.

Nilai utama dari tujuan perusahaan adalah untuk mencapai kepuasan pelanggan. Kepuasan pelanggan ini tentunya dapat tercapai ketika suatu perusahaan dapat memberikan pelayanan yang diharapkan oleh pelanggan. Dua elemen mendasar yang merupakan suatu hal yang sangat dibutuhkan pelanggan yaitu waktu dan kualitas. Pelanggan tentunya menuntut agar suatu perusahaan dapat memberikan waktu pelayanan yang cepat dan efisien tetapi tanpa melupakan kualitas dari produk itu sendiri.

Penerapan Total Quality Management (TQM) dan Just In Time (JIT) merupakan dua strategi untuk mencapai kepuasan pelanggan dari sisi kualitas dan kecepatan suatu layanan perusahaan. Dengan diterapkannya TQM dan JIT diharapkan suatu perusahaan akan dapat mempertahankan continuity. Menurut Prawironegoro dan Purwanti (2008: 326) TQM merupakan suatu cara untuk meningkatkan proses bisnis secara terus menerus, atau cara memperbaiki dan meningkatkan efektivitas dan efisiensi penggunaan sumber daya perusahaan untuk memenuhi kebutuhan pelanggan. Pelanggan adalah sumber laba dalam suatu bisnis, oleh karena itu kebutuhan dan kepuasannya harus ditingkatkan dari waktu ke waktu agar mereka loyal kepada perusahaan. Jadi pada hakikatnya, TQM adalah tindakan mencapai tujuan dengan cara memenuhi kebutuhan dan memuaskan pelanggan melalui kualitas pelayanan pelanggan. Sistem just in time berusaha menghilangkan segala pemborosan dan segala sesuatu yang tidak memberi nilai tambah dengan menyediakan sumber daya pada tempat dan waktu yang tepat. Sistem ini akan mengakibatkan persediaan lebih sedikit, jumlah pekerja lebih sedikit, dan biaya produksi yang lebih rendah serta produk dapat diserahkan ke pelanggan tepat waktu. Kualitas yang sangat tinggi merupakan hasil dari suatu sistem pengendalian mutu yang sangat baik.

Di dalam praktik penerapannya, konsep JIT yang bertujuan untuk mengoptimalkanperformance, khususnya delivery performance, tidak dapat terlepas dari penerapan TQM. Demikian pula sebaliknya, penerapan TQM juga tidak dapat dilepaskan dari penerapan JIT dalam meningkatkan kinerja perusahaan itu sendiri. JIT dan TQM merupakan dua strategi yang paling banyak diaplikasikan di dunia nyata secara luas.Dengan berhasilnya suatu perusahaan menerapkan Total Quality Management dan 
Just In Time diharapkan suatu perusahaan dapat mencapai delivery performance yang optimal.

Terdapat beberapa penelitian mengenai penerapan Total QualityManagement dan Just In Timemengungkapkan hasil yang berbeda. Oleh karena itu, masalah dalam penelitian ini dapat diidentifikasikan dengan menguji pengaruh Total Quality Management dan Just In Time terhadap Delivery Performance pada perusahaan manufaktur.

\section{KAJIAN TEORI}

Dalam penerapannya, JIT dan TQM memiliki persamaan yaitu bertujuan untuk meningkatkan performance perusahaan. JIT bertujuan untuk memberikan produk tepat pada waktunya, sedangkan TQM bertujuan untuk memberikan produk sesuai dengan standar yang ada. Tujuan JIT dan TQM tersebut dikonversikan menjadi delivery performance yaitu pengukuran kinerja yang difokuskan pada ketepatan waktu, ketepatan kualitas dan ketepatan jumlah barang.

Total Quality Management (TQM). TQM adalah filosofi yang menghendaki perubahan perilaku pada semua tingkat organisasi dengan menaruh perhatian pada pentingnya kepuasan konsumen. Filosofi TQM ini menekankan pada sumber daya manusia dan hubungan antar manusia yang tidak hanya mengandalkan pemeriksaan kualitas pada akhir proses, tetapi lebih menitikberatkan pada proses pembentukan kualitas itu sendiri dengan cara menghilangkan penyimpangan-penyimpangan yang terjadi selama proses produksi.

Menurut Besterfield, dkk (2011:1) Total Quality Management "is an enhacement to the traditional way of doing business. It is a proven technique to guarantee survival in world-class competition."

Adapun menurut Charantimath (2009:6) Total Quality Management adalah

"Total Quality Managementis a management approach that tries to achieve and sustainlong-term organizational success by encouraging employee feedback and participation, satisfying customer needs and expectations, respectic societal values and beliefs, and obeying governmental statutes and regulations."

Sementara itu menurut Hansen dan Mowen (2007:13), Total Quality Management "in which manufacturers strive to create an environment that will enable workers to manufacturer perfect (zero-deffect)products, has replaced the acceptable quality attitudes of the past ".

Suharyadi,dkk (2007: 152) berpendapat bahwa Total Quality Management adalah "adanya kemauan dari pengusaha untuk melakukan perbaikan yang dilakukan secara terus menerus, yang melibatkan semua karyawan di setiap level organisasi, untuk menciptakan kualitas yang excellent dalam semua aspek organisasi melalui proses manajemen"

Adapun menurut Nasution (2010:22) Total Quality Management merupakan suatu pendekatan dalammenjalankan usaha yang mencoba untuk memaksimumkan daya saingorganisasi melalui perbaikan terus-menerus atas produk, jasa, tenagakerja, proses, dan lingkungannya.

Berdasarkan pengertian di atas dapat disimpulkan bahwa Total Quality Management (TQM) adalah suatu upaya guna meningkatkan kualitas pada setiap level operasi atau proses melalui perbaikan secara terus-menerus atas produk, jasa, lingkungan, manusia, 
proses, dan lingkungannya. Saat ini banyak perusahaan-perusahaan yang menerapkan TQM dengan tujuan untuk meningkatkan kinerjanya. Menurut Hensler dan Brunell dalam dalam Nasution (2010: 30), ada empat prinsip utama dalam TQM. Keempat prinsip tersebut adalah sebagai berikut: (1) Kepuasan Konsumen. Dalam TQM, suatu kualitas ditentukan oleh konsumen. Konsumen itu sendiri meliputi konsumen internal dan konsumen eksternal. Kebutuhan konsumen diusahakan untuk dipuaskan dalam segala aspek, termasuk di dalamnya harga, keamanan, dan ketepatan waktu. Semakin tinggi nilai yang diberikan, maka semakin besar pula kepuasan konsumen; (2) Respek terhadap Setiap Orang. Perusahaan yang kualitasnya tergolong kelas dunia, memandang bahwa karyawan merupakan sumber daya organisasi yang paling bernilai. Oleh karena itu, setiap orang dalam organisasi diperlakukan dengan baik dan diberi kesempatan untuk terlibat dan berpartisipasi dalam pengambilan keputusan; (3) Manajemen Berdasarkan Fakta. Perusahaan kelas dunia berorientasi pada fakta, yaitu setiap keputusan selalu didasarkan pada data, bukan sekedar pada perasaan (feeling). Dengan menggunakan data,maka manajemen dapat memfokuskan variabilitas kinerja manusia. Data statistik dapat memberikan gambaran mengenai variabilitas yang merupakan bagian yangwajar dari setiap sistem organisasi. Dengan demikian, manajemen dapat memprediksikan hasil dari setiap keputusan dan tindakan yang dilakukan; (4) Perbaikan Berkesinambungan. Untuk melaksanakan perbaikan secara berkesinambungan setiap perusahaan perlu melakukan proses sistematis. Konsep yang berlaku disini adalah PDCAA (plan-do-check-act-analyze) yang terdiri dari langkah-langkah perencanaan dan melakukan tindakan korektif terhadaphasil yang diperoleh.

Elemen Total Quality Management (TQM). Menurut Goetsch dan Davis dalam Nasution (2010:22), terdapat 10 (sepuluh) elemen yang terkandung dalam TQM yaitu: (1) Fokus Pada Konsumen. Dalam TQM, baik konsumen internal maupun eksternal merupakan driver. Konsumen eksternal berperan untuk menentukan kualitas produk atau jasa yang diberikan kepada mereka, sedangkan konsumen internal berperan untuk menentukan kualitas manusia, proses, dan lingkungan yang berhubungan dengan produk atau jasa; (2) Obsesi terhadap Kualitas. Sebuah Organisasi yang menerapkan TQM, baik konsumen internal dan eksternal merupakan penentu kualitas. Dengan kualitas yang ditetapkan tersebut, organisasi harus terobsesi untuk memenuhi atau melebihi apa yang telah ditentukan tersebut, bila suatu organisasi terobsesi dengan kualitas, maka berlaku prinsip 'good enough is never good enough'; (3) Pendekatan Ilmiah. Pendekatan ilmiah dalam penerapan TQM berfungsi untuk mendesain pekerjaan dan dalam proses pengambilankeputusan dan pemecahan masalah yang berkaitan dengan pekerjaanyang didesain tersebut. Dengan demikian, data diperlukan dandipergunakan dalam menyusun patok duga (benchmark), memantauprestasi, dan melaksanakan perbaikan; (4) Komitmen Jangka Panjang. TQM merupakan suatu paradigma baru dalam melaksanakan bisnis.Untuk itu, dibutuhkan budaya perusahaan yang baru pula. Oleh karenaitu, komitmen jangka panjang sangat penting guna mengadakanperubahan budaya agar penerapan TQM dapat berjalan dengan sukses; (5) Kerja Sama Tim. Dalam organisasi yang dikelola secara tradisional sering kalidiciptakan persaingan antardepartemen yang ada dalam organisasi tersebut untuk meningkatkan daya saingnya. Akan tetapi, persainganinternal tersebut cenderung hanya menggunakan dan menghabiskanenergi yang seharusnya dipusatkan pada upaya perbaikan kualitasuntuk meningkatkan daya saing perusahaan padalingkungan eksternal; (6) Perbaikan Sistem Secara Berkesinambungan. 
Setiap produk dan atau jasa dihasilkan melalui proses-proses terntentu di dalam suatu sistem/lingkungan. Oleh karenaitu, perbaikan sistem secara terus-menerus sangat diperlukan agar kualitasyang dihasilkannya dapat terus meningkat; (7) Pendidikan dan Pelatihan. Sebuah organisai yang menerapkan TQM memiliki anggapan bahwa pendidikandan pelatihan merupakan faktor yang fundamental. Setiap orangdiharapkan dan didorong untuk terus belajar. Dengan belajar, setiap orang dalamperusahaan dapat meningkatkan keterampilan teknis dan keahlianprofesionalnya; (8) Kebebasan yang Terkendali. Dalam TQM, melibatkan dan memberdayakan karyawan dalam pengambilan keputusan dan pemecahan masalah merupakan unsur yang sangat penting untuk dapat meningkatkan tanggung jawab karyawan terhadap keputusan yang telah dibuat. Dalam hal ini, karyawanlah yang melakukan standarisasi proses dan mereka pula yang mencari cara untuk meyakinkan setiap orang agar bersedia mengikuti prosedur standar tersebut; (9) Kesatuan Tujuan. Untuk dapat menerapkan TQM dengan baik, suatu perusahaan harusmemiliki kesatuan tujuan. Dengan demikian, setiap usaha dapatdiarahkan pada tujuan yang sama. Akan tetapi, kesatuan tujuan initidak berarti bahwa harus selalu ada persetujuan/ kesepakatan antarapihak manajemen dan karyawan, misalnya mengenai upah dan kondisikerja; (10) Adanya Keterlibatan dan Pemberdayaan Karyawan. Keterlibatan dan pemberdayaan karyawan merupakan hal yang penting dalam penerapan TQM. Usaha untuk melibatkankaryawan membawa dua manfaat utamaa, yaitu untuk meningkatkanperencanaaan dan pengambilan keputusan, serta meningkatkan rasamemiliki dan tanggung jawab atas keputusan dengan melibatkanorang-orang yang harus melaksanakannya.

Tujuan dan Manfaat Total Quality Management. Tujuan TQM adalah untuk perbaikan mutu produk, jasa dan proses, dimana mutu tersebut diperoleh dengan tingkat biaya yang paling ekonomis, yang akan berpengaruh pada produktivitas, kepuasan konsumen, pencapaian laba serta kinerja keuangan perusahaan. Tujuan TQM yang lebih luas adalah untuk menjamin kepemimpinan dengan menetapkan proses dan sistem yang meningkatkan keberhasilan perusahaan, mencegah kesalahan dan pemborosan usaha serta meyakinkan hubungan dengan konsumen.

Terdapat dua manfaat yang diperoleh perusahaan yang menerapkan TQM. Dilihat dari sisi internal, yaitu bila mutu diperbaiki, akan dicapai produktivitas yang lebih tinggi, yang memungkinkan harga yang kompetitif, peningkatan pangsa pasar, dan laba yang lebih tinggi. Dari sisi eksternal manfaat yang akan diperoleh adalah loyalitas konsumen, mendapat lebih banyak pembeli sehingga akan meningkatkan pangsa pasar dan laba.

Menurut Schroeder dan Ahmad (2001:19) perusahaan yang menerapkan TQM akan membangun hubungan yang erat dengan pemasok dan menekankan pada fokus pelanggan. Penerapan manajemen mutu guna memastikan jika proses produksi dapat mengurangi scrap dan pengerjaan ulang, sehingga akan dapat meminimalkan waktu produksi. Dengan adanya pengurangan waktu produksi tentunya akan mengakibatkan barang/jasa yang telah dipesan oleh pelanggan akan sampai lebih cepat. Oleh karena itu, perusahaan yang memiliki program manajemen mutu secara proaktif diharapkanakan memberikan dampak positif pada delivery performance.

Just In Time. Just In Time merupakan sebuah model dimana perusahaan hanya memproduksi atas dasar permintaan tanpa memanfaatkan tersedianya persediaan dan tanpa menanggung biaya persediaan. Setiap operasi hanya memproduksi untuk memenuhi 
permintaan dari operasi berikutnya. Produksi tidak akan terjadi sebelum ada tanda dari proses selanjutnya yang menunjukkan permintaan produksi.

Menurut Hansen dan Mowen (2007:628) Just In Time "is a demand-pull systemthat requires goodsto be pull trough by present demand rather than pushed through the system on a fixed schedulebased on anticipated demand."Sementara itu Russel dan Taylor dalam Meylianti dan Mulia (2009:115) mengungkapkan Just In Time "is a concept minimazing inventory and smoothing the flow of material so that material arrived just as it was needed." Menurut Prawironegoro dan Purwanti (2008:340) Just In Time adalah "persediaan dengan nilai nol atau mendekati nol, artinya perusahaan tidak menanggung biaya persediaan. Bahan baku akan tepat datang pada saat dibutuhkan.”

Berdasarkan pengertian di atas dapat disimpulkan bahwa Just In Time adalah suatu sistem dimana setiap unit kerja didalam perusahaan memproduksi barang yang dibutuhkan pada saat yang dibutuhkan dengan cara yang paling ekonomis dan efisien sehingga sesuatu yang tidak mempunyai nilai tambah atau pemborosan terhadap produk dapat dihilangkan.Sistem Just In Time merupakan upaya untuk mengurangi atau menghilangkan persediaan (dengan memangkas biaya-biaya).

Elemen Just In Time. Menurut Simamora (2012:111), terdapat enam elemen kunci bagi keberhasilan sistem JIT, elemen tersebut meliputi: (1) Jumlah pemasok yang terbatas. Dalam sistem JIT, pemasok diperlakukan sebagai mitra dan biasanya terikat kontrak jangka panjang dengan perusahaan. Para pemasok merupakan bagian vital sistem yang membuat JIT berjalan mulus, memastikan masukan bermutu dan pengiriman yang tepat waktu; (2) Tingkat persediaan yang minimal. Berlawanan dengan lingkungan pabrikasi tradisional, dimana bahan baku, suku cadang, dan pasokan dibeli jauh-jauh hari sebelumnya dan disimpan digudang sampai departemen produksi membutuhkannya, di dalam lingkungan JIT bahan baku dan suku cadang dibeli serta diterima hanya ketika dibutuhkan saja; (3) Pembenahan tata letak pabrik. Dalam sistem JIT tata letak pabrik tradisional dengan suatu pola sel pabrikasi (manufacturing cells) atau sel kerja (work cells). Sel pabrikasi berisi mesin-mesin yang dikelompokan kedalam sebuah keluarga mesin, umumnya berbentuk setengah lingkaran; (4) Pengurangan setup time. Masa pengesetan mesin (setup time) adalah waktu yang dibutuhkan untuk mengubah perlengkapan, memindahkan bahan baku, dan memperoleh dokumen terkait dan bergerak cepat guna mengakomodasikan produksi unsur yang berbeda; (5) Kendali mutu terpadu. Agar JIT berjalan lancar, perusahaan perlu membangun sistem kendali mutu terpadu (total quality control) atas komponen-komponen dan bahan bakunya. TQC berarti bahwa perusahaan tidak boleh menerima komponen dan bahan baku yang cacat dari pemasok, pada barang dalam proses, atau pada barang jadi; (6) Tenaga kerja yang fleksibel. Didalam lingkungan kerja dengan sisten JIT para karyawan harus mengusai bermacam-macam keterampilan teknis. Karyawan diminta mengoperasikan beberapa jenis mesin secara simultan. Praktik JIT memiliki empat elemen utama, yaitu usaha peniadaan atau penghilangan pemborosan, keterlibatan karyawan, partisipasi dari pemasok dan pengawasan kualitas total. Keterlibatan pekerja, manajer, dan pemasok dengan peran yang berbeda-beda yangterfokus pada usaha peniadaan pemborosan dalam proses produksi akan menjamin praktik JIT berhasil meningkatkan kinerja.

Tujuan dan Manfaat Just In Time. Hansen dan Mowen (2007:629) mengemukakan bahwa JITmempunyai dua tujuan strategik yaitu untuk meningkatkan profit dan untuk 
memperbaiki posisi kompetitif perusahaan. Kedua tujuan strategic ini dapat dicapai dengan mengontrol biaya (mendapatkan harga kompetisi yang lebih baik dan meningkatkan profit), memperbaiki kinerja pengiriman dan memperbaiki kualitas produk. JIT memberikan peningkatan efisiensi biaya dan secara simultan dan memiliki fleksibilitasuntuk merespon permintaan konsumen dengan kualitas yang lebih baik dan bervariasi.

Manfaat dari penerapan sistem Just In time menurut Garrison \& Norren (2008:17) adalah: Modal kerja dapat ditunjang dengan adanya penghematan karena pengurangan biaya-biaya persediaan, lokasi yang tadinya untuk menyimpan persediaan dapat digunakan untuk aktivitas lain sehingga produktivitas meningkat, waktu untuk melakukan aktivitas produksi berkurang, sehingga dapat menghasilkan jumlah produk lebih banyak dan lebih cepat merespon konsumen, dan tingkat produk cacat akan berkurang sehingga mengakibatkan penghematan dan kepuasan konsumen meningkat.

Banyaknya manfaat yang diperoleh dari penerapan JIT karena itu semakin banyak perusahaan yang menggunakan sistem JIT. Menurut Schroeder dan Ahmad (2001:19) perusahaan yang menerapkan sistem JIT secara berkesinambungan terus berupaya untuk mengurangi waktu set-up dan ukuran lot yang dimiliki melalui pekerja yang memiliki multi-keterampilan dan layout peralatan yang fleksibel. Perusahaan yang menerapkan JIT akan selalu berusaha untuk mempertahankan hubungan dekat baik dengan pelanggan ataupun pemasok mereka untuk mendukung rantai nilai yang berdasarkan pull system. Dengan diterapkannya pull system diharapkan jumlah persediaan yang dimiliki akan dapat diminimalisir dan kelancaran aliran bahan baku dipastikan akan sampai tepat pada saat dibutuhkan. Berdasarkan hal ini, penerapan JIT diharapkan akan memberikan pengaruh terhadap delivery performance.

Delivery Performance. Peformance (kinerja) adalah hasil kerja yang dapat dicapai oleh seorang atau sekelompok orang dalam suatu organisasi, sesuai dengan wewenang dan tanggung jawab masing-masing, dalam rangka upaya dalam pencapaian tujuan organisasi bersangkutan secara legal, tidak melanggar hukum, dan sesuai dengan moral maupun etika (Suyadi, dalam Supratingrum dan Zulaikha, 2002:13).

Menurut Rao, Rao, dan Muniswamy (2011:205) Delivery performance“can be defined as the level up to which products and services supplied by an organization meet the customer expectation."

Kinerja pengiriman (Delivery Performance) adalah suatu kinerja yang digunakan untuk menunjukkan seberapa baik perusahaan dapat memenuhi permintaan pelanggan dan meningkatkan kemungkinan menerima pesanan tambahan dari para pelanggan.

Menurut Meylianti dan Mulia (2009:119) pengukuran delivery performance didasarkan pada tiga aspek umum yaitu time,cost, dan quality. Menurut Finch dalam Meylianti dan Mulia (2009:119) waktu yang telah dijanjikan dalam mengirimkan barang adalah hal yang sangat penting. Menurut Finch kualitas pelayanan jauh lebih penting dibandingkan kualitas produk itu sendiri. Untuk mewujudkan kualitas pelayanan yang baik, perusahaan harus dapat menciptakan serangkaian mekanisme operasi untuk mengirimkan barang dan jasa seefisien mungkin. Salah satu cara guna memenuhi permintaan pelanggan secara cepat adalah bagaimana membuat bahan baku sampai di tangan secara tepat waktu. Apabila bahan baku telah sampai, kemampuan perusahaan untuk memproduksi barang-barang tersebut tanpa penundaan adalah hal yang sangat penting, hal ini guna memastikan bahwa proses produksi efisien serta hemat biaya. Faktor 
lain seperti pengelolaan pengiriman seperti pemilihan pengirim atau kurir sangat penting ketika perusahaan mengevaluasi kinerja pengiriman.

Manfaat yang diperoleh perusahaan dengan pencapaian kinerja pengiriman yang baik mencakup peningkatan tingkat kepuasan pelanggan, terutama ketika pengiriman barang-barang atau jasa tidak hanya mampu memenuhi harapan pelanggan tetapi melebihi harapan mereka. Manfaat lain yang jelas diperoleh dari kinerja pengiriman yang baik adalah meningkatnya pendapatan perusahaan yang dihasilkan dari pelanggan ingin kembali lagi untuk memperoleh barang dan jasa selain yang mereka inginkan.

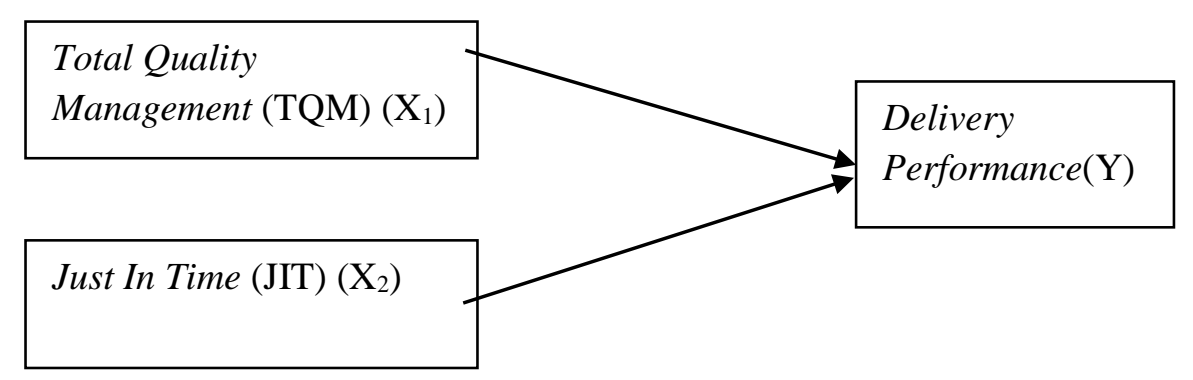

Hipotesis/ Berdasarkan landasan teori dan hasil empiris penelitian terdahulu, maka dapat ditarik beberapa hipotesis sebagai berikut:

$\mathrm{Ha}_{1}$ : Total Quality Management (TQM) memiliki pengaruh yang signifikan terhadap Delivery Performance.

Ha2: Just In Time (JIT) memiliki pengaruh yang signifikan terhadap Delivery Performance.

\section{METODE}

Objek penelitian dalam penelitian ini adalah Delivery Performance pada perusahaan manufaktur. Pemilihan sampel dalam penelitian ini menggunakan purposive sampling yaitu dengan menggunakan kriteria tertentu dalam melakukan pemilihan sampel. Kriteriakriteria tersebut adalah perusahaan-perusahaan manufaktur yang telah menerapkan Total Quality Management (TQM) dan Just In Time (JIT). Sampel yang digunakan termasuk kelompok perusahaan manufaktur yang terdapat di Bogor dan Tangerang.

Data yang digunakan dalam penelitian ini adalah data primer. Kuesioner ini diajukan kepada para pegawai yang menjadi sampel penelitian ini. Kuesioner diberikan dengan mendatangi perusahaan secara langsung. Kuesioner yang digunakan terdiri dari tiga bagian, yaitu kuesioner untuk meneliti Total Quality Management yang terdiri dari 14 buah pertanyaan, kuesioner untuk meneliti Just In Time yang terdiri 25 buah pertanyaan, dan kuesioner untuk meneliti Delivery Performance terdiri dari 5 pertanyaan. Seluruh pertanyaan mengenai variabel-variabel tersebut diukur dengan menggunakan skala likert poin 1 sampai dengan poin 5. Jumlah kuesioner yang dibagikan berjumlah 148 buah dan sebanyak 134 buah yang dapat ditarik kembali.

Variabel penelitian ini terdiri dari variabel independen dan variabel dependen. Variabel independen dalam penelitian ini adalah Total Quality Management dan Just In Time, sedangkan variabel dependen adalah Delivery Performance. 
Analisis regresi bertujuan untuk mengetahui hubungan antara satu variabel independen terhadap variabel dependen. Bentuk hubungan linier berganda dalam penelitian ini adalah:

$$
\mathrm{Y}=\alpha+\beta_{1} \mathrm{TQM}+\beta_{2} \mathrm{JIT}+\mathbf{e}
$$

Dimana: $\mathrm{Y}=$ Delivery Performance; $\alpha=$ Konstanta atau nilai variabel terikat $(\mathrm{Y})$ jika besar perubahan nilai variabel (X) sama dengan 0; $\beta_{1}=$ koefisien regresi Total Quality Management; $\beta_{2}=$ koefisien regresi Just In Time; TQM = Total Quality Management; JIT = Just In Time; $e=$ error

\section{Operasionalisasi Variabel}

Tabel 1. Operasionalisasi Variabel

\begin{tabular}{cccc}
\hline Interval & Indikator & Skala & Item Pengukur \\
\hline $\begin{array}{c}\text { Total Quality } \\
\text { Management } \\
(\text { TQM) }\end{array}$ & Customer Focus & Interval & Pertanyaan Nomor 1-4 \\
& Product Design & Interval & Pertanyaan Nomor 5-8 \\
& Statistical Process & & \\
& Control (SPC) & Interval & Pertanyaan Nomor 9-14 \\
& Kanban & Interval & Pertanyaan Nomor 15-18 \\
Lot Size & Interval & Pertanyaan Nomor 19-20 \\
(JIT) & Set Time & Interval & Pertanyaan Nomor 21-24 \\
& Schedul & Interval & Pertanyaan Nomor 25-27 \\
& Supplier & Interval & Pertanyaan Nomor 28-34 \\
Delivery & Customer Rel & Interval & Pertanyaan Nomor 35-39 \\
Performance & Delivery & Interval & Pertanyaan Nomor 40-44 \\
\hline
\end{tabular}

\section{HASIL DAN PEMBAHASAN}

\section{Pengujian Statistik Deskriptif}

Tabel 2. Descriptive Statistics Total Quality Management ( $\left.\mathrm{X}_{1}\right)$

Descriptive Statistics

\begin{tabular}{lcrrrr}
\hline & N & Minimum & Maximum & Mean & \multicolumn{2}{l}{$\begin{array}{l}\text { Std. } \\
\text { Deviation }\end{array}$} \\
\hline Customer Focus1 & 134 & 2 & 5 & 3.95 & .629 \\
Customer Focus2 & 134 & 2 & 5 & 3.63 & .810 \\
Customer Focus3 & 134 & 2 & 5 & 3.81 & .761 \\
Customer Focus4 & 134 & 2 & 5 & 3.97 & .612 \\
Product Design 1 & 134 & 2 & 5 & 3.13 & .789 \\
Product Design 2 & 134 & 2 & 5 & 3.69 & .758 \\
Product Design 3 & 134 & 3 & 5 & 4.39 & .587
\end{tabular}




\begin{tabular}{lccccc}
\hline \hline & & & & & \\
Product Design 4 & 134 & 2 & 5 & 4.30 & .588 \\
Statistical Process Control 1 & 134 & 2 & 5 & 3.84 & .639 \\
Statistical Process Control 2 & & & & & \\
Statistical Process Control 3 & 134 & 2 & 5 & 3.90 & .640 \\
Statistical Process Control 4 & 134 & 2 & 5 & 3.66 & .785 \\
Statistical Process Control 5 & 134 & 2 & 5 & 3.83 & .781 \\
Statistical Process Control 6 & 134 & 1 & 5 & 3.65 & .843 \\
Valid N (listwise) & 134 & 2 & 5 & 3.75 & .789 \\
\hline
\end{tabular}

Tabel 3. Descriptive Statistics Just In Time $\left(\mathrm{X}_{2}\right)$

Descriptive Statistics

\begin{tabular}{|c|c|c|c|c|c|c|}
\hline & $\mathrm{N}$ & Minimum & Maximum & & Tean & Std. Deviation \\
\hline Kanban 1 & 134 & & 1 & 5 & 3.69 & .952 \\
\hline Kanban 2 & 134 & & 1 & 5 & 3.79 & .918 \\
\hline Kanban 3 & 134 & & 1 & 5 & 3.96 & .750 \\
\hline Kanban 4 & 134 & & 1 & 5 & 3.94 & .754 \\
\hline Lot 1 & 134 & & 1 & 5 & 3.55 & .809 \\
\hline Lot 2 & 134 & & 1 & 5 & 3.59 & .758 \\
\hline Set-Up 1 & 134 & & 1 & 5 & 4.13 & .874 \\
\hline Set-up 2 & 134 & & 1 & 5 & 3.50 & .994 \\
\hline Set-up 3 & 134 & & 1 & 5 & 4.07 & .915 \\
\hline Set-up 4 & 134 & & 1 & 5 & 4.20 & .916 \\
\hline Schedule 1 & 134 & & 1 & 5 & 3.91 & .770 \\
\hline Schedule 2 & 134 & & 2 & 5 & 3.57 & .779 \\
\hline Schedule 3 & 134 & & 2 & 5 & 3.83 & .751 \\
\hline Supplier 1 & 134 & & 3 & 5 & 3.93 & .609 \\
\hline Supplier 2 & 134 & & 2 & 5 & 3.83 & .689 \\
\hline Supplier 3 & 134 & & 3 & 5 & 4.42 & .566 \\
\hline Supplier 4 & 134 & & 3 & 5 & 3.93 & .696 \\
\hline Supplier 5 & 134 & & 3 & 5 & 4.02 & .619 \\
\hline Supplier 6 & 134 & & 3 & 5 & 4.07 & .485 \\
\hline Supplier 7 & 134 & & 2 & 5 & 3.96 & .573 \\
\hline Customer Rel 1 & 134 & & 2 & 5 & 4.21 & .716 \\
\hline Customer Rel 2 & 134 & & 2 & 5 & 4.04 & .750 \\
\hline Customer Rel 3 & 134 & & 3 & 5 & 4.28 & .580 \\
\hline Customer Rel 4 & 134 & & 3 & 5 & 3.99 & .569 \\
\hline Customer Rel 5 & 134 & & 2 & 5 & 3.92 & .694 \\
\hline $\begin{array}{l}\text { Valid N } \\
\text { (listwise) }\end{array}$ & 134 & & & & & \\
\hline
\end{tabular}


Tabel 4. Descriptive statistics Delivery Performance (Y)

Descriptive Statistics

\begin{tabular}{lrrrrr}
\hline & N & Minimum & Maximum & Mean & \multicolumn{2}{l}{ Std. Deviation } \\
\hline Delivery 1 & 134 & 3 & 5 & 3.91 & .607 \\
Delivery 2 & 134 & 3 & 5 & 3.94 & .646 \\
Delivery 3 & 134 & 3 & 5 & 4.39 & .561 \\
Delivery 4 & 134 & 3 & 5 & 3.99 & .562 \\
Delivery 5 & 134 & 2 & 5 & 3.92 & .694 \\
Valid N (listwise) & 134 & & & & \\
\hline
\end{tabular}

Pengujian Instrumen Pengumpulan Data. Pertama. Uji Validitas Data. Di dalam pengujian ini dilakukan dengan membandingkan $\mathrm{r}$ yang dihitung dengan nilai $\mathrm{r}$ tabel. Apabila nilai $r$ hitung $>r$ tabel, maka pertanyaan yang mewakili variabel tersebut dikatakan valid sedangkan apabila nila $\mathrm{r}$ hitung $<\mathrm{r}$ tabel, maka pertanyaan yang mewakili variabel tersebut dikatakan tidak valid. Nilai $\mathrm{r}$ hitung dapat ditunjukkan pada kolom corrected item total correlation sedangkan nilai $\mathrm{r}$ tabel dengan jumlah 134 responden pada taraf signifikansi 0,05 (signifikansi 5\%) yaitu sebesar 0,1416. Hasil pengujian validitas menunjukkan dari 44 item pertanyaan secara keseluruhan dinyatakan valid. Kedua. Uji Reliabilitas

Tabel 5. Hasil Uji Reliabilitas

\begin{tabular}{lll}
\hline Variabel & Cronbach's Alpha & N of items \\
\hline Total Quality Management & .830 & 14 \\
Just In Time & .879 & 25 \\
Delivery Performance & .728 & 5 \\
\hline
\end{tabular}

Dari hasil perhitungan reliabilitas diperoleh nilai Cronbach's Alpha untuk variabel Total Quality Management, Just In Time dan Delivery Performance berturut-turut adalah 0,830; 0,879; 0,728. Semua nilai Cronbach's Alpha mendekati 1, berarti butir-butir pertanyaan variabel-variabel tersebut reliabel untuk digunakan.

\section{Pengujian Asumsi Klasik}

Tabel 6. Hasil Uji Normalitas

One-Sample Kolmogorov-Smirnov Test

\begin{tabular}{lll}
\hline & & $\begin{array}{l}\text { Unstandardized } \\
\text { Residual }\end{array}$ \\
\hline $\mathrm{N}$ & & 134 \\
Normal Parameter a.b & Mean & .0000000 \\
& Std. Deviation & 1.63228239 \\
& Absolute & .043 \\
Most Extreme Differences & Positive & .043 \\
& Negative & -.030 \\
Kolmogorov-Smirnov Z & & .493 \\
Asymn. Sig. (2-talled) & & .968
\end{tabular}

a. Test distribution is Normal

b. Calculated from data 
Berdasarkan uji normalitas dengan menggunakan metode Kolmogorov Smirnov seperti pada tabel di atas dapat disimpulkan bahwa data terdistribusi normal. Hal ini terlihat dari nilai Asymp. Sig (2-tailed) 0,968 > 0,05.

a. Uji Heteroskedastisitas

Tabel 7. Hasil Uji Heteroskedastisitas

Coefficients

\begin{tabular}{ccc}
\hline Model & $\mathrm{t}$ & Sig. \\
\hline (Constant) & -.559 & .577 \\
$\ln 1$ & -1.466 & .145 \\
$\ln x 2$ & 1.631 & .105 \\
\hline
\end{tabular}

a. Dependent Variable: Inei

Uji Heteroskedastisitas dalam penelitian ini menggunakan uji park. Data dikatakan tidak heteroskedastisitas apabila signifikansinya lebih besar dari 0,05 atau 5\%. Dari tabel diatas, dapat dilihat bahwa signifikansi dari total quality management dan just in time lebih besar dari 0,05 .

b. Uji Multikolinieritas

Tabel 8. Hasil Uji Multikolinearitas

\section{Coefficients $^{\mathrm{a}}$}

\begin{tabular}{llll}
\hline Model & \multicolumn{2}{c}{ Collinearity } & Statistics \\
\cline { 3 - 4 } & & Tolerance & VIF \\
\hline & (Constant) & & \\
& TQM & .707 & 1.415 \\
1 & JIT & .707 & 1.415 \\
\hline
\end{tabular}

Dependent Variable: Delivery Performance

Deteksi adanya multikolinearitas dengan melihat nilai Variance Inflation Factor (VIF) dan tolerance. Apabila VIF $>10$ dan nilai tolerance $<0,1$ maka variabel tersebut mempunyai masalah multikolinieritas. Pada Tabel 8 dapat dilihat bahwa nilai VIF dan tolerance dari total quality management dan just in time tidak melewati dari batas yang telah ditentukan maka dapat dikatakan variabel tersebut bebas dari multikolinearitas.

\section{Pengujian Hipotesis}

\section{a. Uji Statistik F (Anova)}

Tabel 9. Hasil Uji Statistik F

\begin{tabular}{|c|c|c|c|c|c|c|}
\hline \multicolumn{7}{|c|}{ ANOVA $^{a}$} \\
\hline & del & $\begin{array}{l}\text { Sum of } \\
\text { Squares }\end{array}$ & $\mathrm{df}$ & & & Sig. \\
\hline \multirow{3}{*}{1} & Regression & 249.948 & 2 & 124.974 & 46.201 & $.000^{\mathrm{b}}$ \\
\hline & Residual & 354.358 & 131 & 2.705 & & \\
\hline & Total & 604.306 & 133 & & & \\
\hline
\end{tabular}

a. Dependent Variable: Delivery Performance

b. Predictors: (Constant), JIT, TQM 
Berdasarkan Tabel 9, hasil uji F menunjukkan tingkat signifikansi di bawah $0.05(0.000<$ 0.05) yang menandakan bahwa model regresi memiliki kriteria fit atau layak untuk digunakan. Nilai signifikansi sebesar 0.000 juga menandakan bahwa total quality management $\left(\mathrm{X}_{1}\right)$ dan just in time $\left(\mathrm{X}_{2}\right)$ memiliki pengaruh secara simultan yang signifikan atau memiliki kesesuaian terhadap variabel delivery performance (Y) dengan tingkat keyakinan 95\%.

b. Uji Koefisien Korelasi dan Koefisien Determinasi

Tabel 10. Hasil Uji Koefisien Korelasi dan Koefisien Determinasi

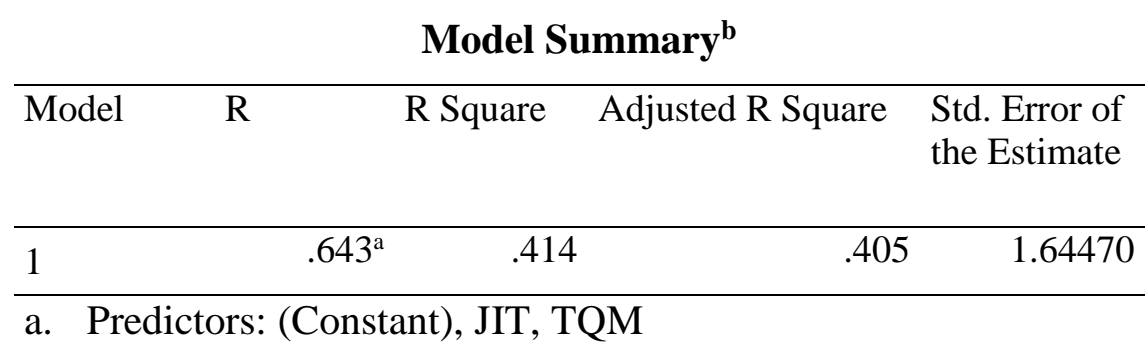

b. Dependent Variable: Delivery Performance

Berdasarkan Tabel 10, diperoleh nilai korelasi (R) sebesar 0,643. Nilai korelasi (R) menunjukan adanya hubungan yang kuat antara variabel total quality management dan just in time terhadap delivery performance. Untuk nilai koefisien determinasi (adjusted $\mathrm{R}^{2}$ ) sebesar 0,405. Hal ini menunjukkan bahwa persentase sumbangan pengaruh variabel total quality management dan just in time terhadap variabel delivery performance sebesar 40,5\%, sedangkan sisanya sebesar 59,5\% dijelaskan atau dipengaruhi oleh variabel lain yang tidak dimasukkan dalam model penelitian ini.

c. Uji Statistik t (secara parsial)

Tabel 11. Hasil Uji Statistik t

\begin{tabular}{|c|c|c|c|c|c|}
\hline \multirow[t]{2}{*}{ Model } & \multicolumn{2}{|c|}{ Unstandardized Coefficients } & \multirow{2}{*}{$\begin{array}{c}\text { Standardized } \\
\text { Coefficients } \\
\text { Beta }\end{array}$} & \multirow[t]{2}{*}{$\mathrm{t}$} & \multirow[t]{2}{*}{ Sig. } \\
\hline & B & Std. Error & & & \\
\hline (Constant) & 4.604 & 1.623 & & 2.837 & .005 \\
\hline TQM & .122 & .030 & .321 & 4.035 & .000 \\
\hline JIT & .092 & .018 & .410 & 5.149 & .000 \\
\hline
\end{tabular}

a. Dependent Variable: Delivery Performance

Berdasarkan Tabel 11, variabel total quality management memiliki nilai signifikansi sebesar 0.000 yaitu lebih kecil dari 0.05 . Hal tersebut menunjukkan bahwa variabel total quality management memiliki pengaruh yang signifikan terhadap variabel delivery performance. Dengan demikian dapat disimpulkan bahwa hipotesis pertama diterima. Tujuan diterapkannya TQM adalah guna memastikan adanya peningkatan atas kualitas produk yang dihasilkan perusahaan sehingga akan mengurangi adanya produk cacat serta pemborosan-pemborosan yang terjadi selama proses produksi. Dari peningkatan kualitas inilah akan mengakibatkan barang/jasa menjadi lebih cepat diproduksi sehingga barang/jasa yang telah dipesan oleh pelanggan akan sampai lebih cepat. Oleh karena itu, 
perusahaan yang memiliki program manajemen mutu secara proaktif diharapkan akan memberikan dampak positif pada delivery performance. Hasil penelitian ini sejalan dengan hasil penelitian yang dilakukan Meylianti dan Mulia (2009) bahwa total quality management memiliki pengaruh secara positif terhadap delivery performance.

Variabel just in time memiliki nilai signifikansi sebesar 0.000 yaitu lebih kecil dari 0.05. Hal tersebut menunjukkan bahwa variabel just in time memiliki pengaruh yang signifikan terhadap variabel delivery performance. Dengan demikian dapat disimpulkan bahwa hipotesis kedua juga diterima. Perusahaan yang menerapkan JIT haruslah menggunakan sumberdaya yang dimiliki seefisien mungkin, seperti bagaimana perusahaan menyusun jadwal yang efektif (scheduling) serta memiliki hubungan kerja sama yang baik dengan pemasok. Salah satu manfaat yang diproleh bila mempuyai hubungan yang baik dengan pemasok adalah memperlancar supply chain dari perusahaan karena pemasok akan dapat mengirimkan pasokan bahan baku yang lebih cepat tiba di perusahaan sehingga proses produksi dapat berjalan lebih cepat. Penyusunan jadwal yang efektif juga merupakan suatu upaya dalam meningkatkan delivery performance. Suatu perusahaan memiliki jadwal yang efektif tentunya akan dapat meningkatkan kemampuan perusahaan dalam memenuhi pesanan konsumen, menurunkan persediaan, memproduksi dalam ukuran lot yang lebih kecil serta mengurangi barang dalam proses, hal ini tentunya akan dapat meningkatkan delivery performance. Hasil ini tidak sejalan dengan hasil penelitian yang dilakukan Meylianti dan Mulia (2009), namun hasil penelitian ini sejalan dengan hasil penelitian yang dilakukan oleh Ahmad dan Schroeder (2001) dan Flynn, Sakakibara, dan Schroeder (1995).

Interpretasi Model Regresi. Berdasarkan nilai $\beta$ constant, maka model regresi linear berganda yang terbentuk adalah:

$$
\mathrm{Y}=4,604+0,122 \mathrm{TQM}+0,092 \mathrm{JIT}+\mathrm{e}
$$

Nilai konstanta $(\alpha)$ menunjukkan angka sebesar 4,604. Hal ini berarti jika variabel total quality management dan just in time sama dengan nol maka nilai delivery performance sebesar 4,604. Koefisien regresi variabel total quality management adalah sebesar 0,122 artinya, apabila variabel just in time bernilai konstan, maka setiap kenaikan total quality management sebesar 1 satuan maka nilai delivery performance akan mengalami peningkatan sebesar 0,122. Koefisien regresi variabel just in time adalah sebesar 0,092 artinya, apabila variabel total quality management bernilai konstan, maka setiap kenaikan just in time sebesar 1 satuan maka nilai delivery performance akan mengalami peningkatan sebesar 0,092.

\section{PENUTUP}

Simpulan. Berdasarkan hasil penelitian yang dilakukan, maka dapat disimpulkan bahwa variabel total quality management dan just in time memiliki pengaruh terhadap variabel delivery performance. Hasil penelitian ini juga menunjukkan bahwa penerapan total quality management dan just in time merupakan dua elemen yang saling berkaitan dan apabila suatu perusahaan dapat menerapkan Total Quality Management dan Just In Time secara simultan maka akan dapat meningkatkan Delivery Performance perusahaan 
tersebut, sehingga dengan adanya peningkatan Delivery Performance maka perusahaan dapat meningkatkan kualitasnya secara optimal.

Saran. Penelitian ini memiliki beberapa keterbatasan yaitu terbatasnya ruang lingkup penelitian yaitu hanya perusahaan manufaktur yang berada di wilayah Bogor dan Tangerang, padahal jumlah perusahaan manufaktur tidak hanya di wilayah Bogor dan Tangerang. Selain itu variabel yang dipakai dalam penelitian ini hanya 2 yaitu total quality management dan just in time.

Berikut beberapa saran yang dapat dijadikan masukan bagi para peneliti selanjutnya yaitu untuk penelitian selanjutnya diharapkan dapat melakukan penelitian dengan menggunakan perusahaan manufaktur yang jumlahnya lebih banyak lagi jumlahnya dan tidak hanya terbatas pada wilayah Bogor dan Tangerang untuk lebih mengetahui seberapa baik perusahaan yang menerapkan sistem total quality management dan just in time dalam meningkatkan delivery performance. Para peneliti selanjutnya diharapkan dapat menambah variabel lainnya sebagai faktor yang mempengaruhi delivery performance pada perusahaan.

\section{DAFTAR RUJUKAN}

Besterfield, Dale H. (2011) Total Quality Management. New Delhi: Darling Kindersley Pvt Ltd

Charantimath, Poormina M. (2009) Total Quality Management. New Delhi: Darling Kindersley Pvt Ltd

Flynn, B.B., Sakakibara, S., and Schroeder, R.G. (1995) Relationship between JIT and TQM: practices and performance. International Journal of Academic Research. 38 (3). hal 1325-1360.

Garrison, Ray H, Noreen, Eric W, Brewer, Peter C. (2008) Managerial Accounting. $12^{\text {th }}$ ed. Boston: McGraw-Hill/Irwin

Ghozali, Imam (2012) Aplikasi Analisis Multivariate Dengan Program SPSS. Semarang: Badan Penerbit Universitas Diponegoro.

Hansen, Don R dan Mowen, Maryanne M. (2007) Management Accounting. $8^{\text {th }}$ ed. Ohio: South Wester Publishing Co

Meylianti, B., dan Mulia, F. (2009) "Pengaruh penerapan Just In Time dan (Total Quality Management) terhadap Delivery Performance pada Industri Otomotif di Indonesia. Mei 2009”. Jurnal Manajemen Teori dan Terapan. 2(2). hal 112-127

Nasution, M.N (2010) Manajemen Mutu Terpadu. Edisi Kedua. Bogor:Ghalia Indonesia.

Prawironegoro, Darsono dan Purwanti, Ari. 2008. Akuntansi Manajemen. Edisi Kedua. Jakarta:Mitra Wacana Media.

Rao, C. Madhusudhana, Rao, K. Prahlada and Muniswamyc, V.V. (2011) "Delivery Performance Measurement In An Integrated Supply Chain Management”. Serbian Journal of Management. 6 (2). hal 205-220

Schroeder, Roger G., dan Ahmad, Sohel, (2001) "The Impact Of Electronic Data Interchange On Delivery Performance”. An International Journal. 10(1). hal:16-30

Simamora, Henry. (2012) Akuntansi Manajemen. Edisi Ketiga. Yogyakarta:Diandra Primamitra.

Sufren dan Natanael. (2014) Belajar Otodidak SPSS Pasti Bisa. Jakarta: PT Elex Media Komputindo. 
Suharyadi,dkk. (2007) Kewirausahaan;Membangun Usaha Sukses Sejak Usia Muda. Jakarta:Salemba Empat

Supranto, J. (2009) Statistik Teori dan Aplikasi. Edisi Ketujuh. Jakarta: Erlangga

Supratiningrum dan Zulaikha. (2003) Pengaruh Total Quality Management Terhadap Kinerja Manajerial dengan Sistem Pengukuran Kinerja dan Sistem Penghargaan (Reward) Sebagai Variabel Moderating (Studi Empiris Pada Hotel di Indonesia).Simposium Nasional Akuntansi VI. hal 775-789 